\section{Verdighet i livets sluttfase}

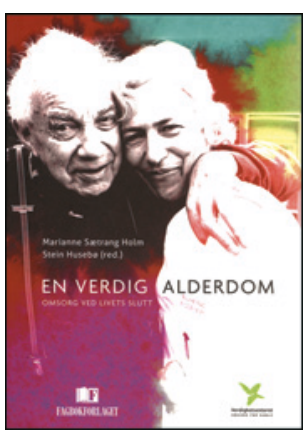

Marianne Sætrang Holm, Stein Husebø, red. En verdig alderdom

Omsorg ved livets slutt. 334 s, tab, ill. Bergen: Fagbokforlaget, 2014. Pris NOK 549 ISBN 978-82-450-1649-9

Omsorg og verdighet for de eldre er et viktig tema. Fra Verdighetssenteret - omsorg for gamle, som er en stiftelse og et nasjonalt kompetansesenter, kommer denne første i en serie på tre bøker. De to andre har titlene Frivillig innsats - eldreomsorg og Verdighetsboken.

Dette er en artikkelsamling med 25 kapitler skrevet av forskjellige fagfolk med ulikt ståsted, fra helsefag, teologi, samfunnsfag og arkitektur. Målgruppen er fagpersonalet og «fotfolket» innen eldreomsorgen, i tillegg til allmennheten.

Temaet er den aller siste fasen i livet - og handler hovedsakelig om personer med demens i sykehjem. Jeg er helt enig i at det spesielt er disse personene som risikerer å miste sin verdighet når de er i en omsorgssituasjon. En verdig alderdom i bredere forstand, som prioriteringer i helsevesenet og diskriminering med hensyn til alder og skrøpelighet, er lite omtalt.

Med bakgrunn som geriater synes jeg det er mange gode og leseverdige kapitler, men vil spesielt fremheve Behandlingskultur og verdighet av Ingunn Moser, Munnstell av Gunhild Strand og Det siste stell av Marianne Sætrang Holm, Tone M. Norekvål og Nina Fålund. Dette er kapitler med stor nytteverdi for dem som jobber i sykehjem og som det er skrevet relativt lite om på norsk. Her lykkes forfatterne i å vise hvordan verdigheten kan ivaretas med praktiske handlinger. Bettina Husebøs Vurdering og behandling av smerte hos pasienter med demens er også et godt kapittel med viktige kjøreregler for forbedret klinisk praksis. Den delen som forklarer sammenhengen mellom nevropatologiske forandringer og smerte har et innviklet språk og vil være vanskelig å forstå for personer uten høy helsefaglig kompetanse.

Når skal man gi palliativ pleie - rent lindrende og ikke lenger livsforlengende behandling? Selv for erfarne leger er det ikke alltid så lett å gjøre denne vurderingen og vite når tiden er inne. En veiledning i hvordan det bør gjøres, med fallgruver og utfordringer, hadde vært fint å ha med.

Språket har varierende kvalitet, og det er skjemmende at begrepet «demente» brukes om "personer med demens». Det hadde også vært mer ryddig om man konsekvent hadde omtalt legemidler med generiske navn (for eksempel diazepam i stedet for Stesolid), all den tid mange legemidler finnes med flere produsentnavn.

Mange av kapitlene har pasienthistorier som gjør lesingen lettere og de viktige budskapene lettere å forstå.

Det er prisverdig at Holm \& Husebø har laget denne artikkelsamlingen. De holder fanen høyt når det gjelder å bidra til at de skrøpeligste gamle i livets sluttfase får beholde sin verdighet. Det skal de ha takk for - og jeg anbefaler gjerne boken til dem som arbeider i sykehjem og til dem som har ansvar for å utforme og kvalitetsforbedre behandling og omsorg i livets sluttfase.

\section{En farlig livsfase}

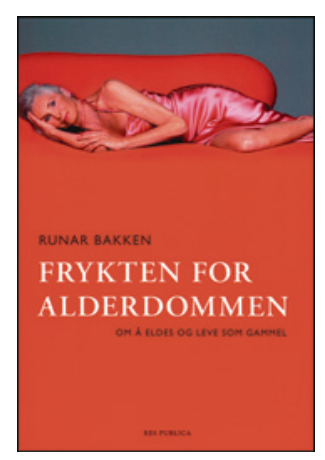

Runar Bakken

Frykten for alderdommen

Om å eldes og leve som gammel. 220 s, ill.

Oslo: Res Publica, 2014. Pris NOK 298

ISBN 978-82-8226-053-4

Runar Bakken er gerontolog, sykepleier og dosent ved Høgskolen i Telemark. I boken går han løs på myten om «den gode alderdommen». Det er meget begrenset hvor god alderdommen kan bli, mener Bakken, for det er en livsfase som ugjenkallelig vil være preget av biologisk forfall, risiko for å bli avhengig av hjelp, og som til sjuende og sist leder mot døden. Det er, og vil alltid være, farlig å være gammel. Fra dette perspektivet studerer og kommenterer forfatteren flere fenomener $i$ vår tid, slik som dyrkingen av den unge kroppen, anbefalingene om fysisk aktivitet langt inn i livets aller siste fase, og mål- og resultatstyringen i kommunal eldreomsorg. Én av hans teser er at den store vekten på aktivitet i alderdommen ikke utelukkende er gunstig sett fra de eldres synspunkt, men like mye skyldes samfunnets behov for å begrense omsorgsbehovet. Det som ikke drøftes, men som ville gitt fremstillingen et ytterligere løft, er hvorvidt det er mulig å ha det godt også som svak og hjelpetrengende. Bakken synes, som de fleste i vårt samfunn, å ta det for gitt at tap av autonomi nødvendigvis betyr tap av livskvalitet. Denne antakelsen kunne gjerne vært utfordret.

Budskapet er pessimistisk: Ikke kan alderdommen uten videre bli god, og ikke vil samfunnet ha vilje eller økonomi til å gi oss en så god alderdom som mulig. Forfatteren er også kritisk til det å gjøre alderdomsrelaterte utfordringer til et medisinsk prosjekt. For herværende anmelder, som bruker sin arbeidstid til å forsøke å hjelpe gamle til å gjenvinne helse og funksjon, og mye av sin fritid til å arbeide for et godt helsevesen for den samme gruppen, er dette utfordrende lesing. Likevel mener jeg Bakkens perspektiv er verdt å ta med seg. Selv om jeg ikke er enig i alt, og kanskje nettopp derfor, er det sunt å la seg utfordre av hans analyse. Mange av hans analytiske ansatser er konstruktive og nyttige, ikke minst som supplement til et medisinsk perspektiv.

Bokens største svakhet er at den gaper litt for høyt. Som det står om den på nettsidene til forfatterens arbeidsplass: «Boka ... er innom en rekke temaer. Alderdom i enkelte stammesamfunn, alderdom som den andre barndom, den gode alderdommen, velferdsstaten og å leve mellom liv og død er noen av temaene». Nettopp. Det er i overkant mye, og forfatteren har ikke kommet helt i mål med å disponere en så bred fremstilling tilstrekkelig stringent. Resultatet er bl.a. en del gjentakelser og enkelte platte trivialiteter. Men her er også virkelige gullkorn! Hvis det blir en ny utgave, bør den kortes ned og strammes inn slik at gullkornene trer bedre frem. Men allerede nå anbefales boken for alle som kjenner en gammel.

\section{Torgeir Bruun Wyller}

Professor, Geriatrisk avdeling

Oslo universitetssykehus 